Rapp. Grønlands geol. Unders. 106, 7-14 (1981)

\title{
NON-EXISTENCE OF THE CAROLINIDIAN OROGENY IN THE PRINSESSE CAROLINE-MATHILDE ALPER OF KRONPRINS CHRISTIAN LAND, EASTERN NORTH GREENLAND
}

\author{
Hans F. Jepsen and Feiko Kalsbeek
}

In 1961 John Haller proclaimed the presence of an older, pre-Caledonian, orogeny in the northern part of the Caledonian fold belt of East Greenland. Haller called it the 'Carolinidian orogeny' after the Prinsesse Caroline-Mathilde Alper in Kronprins Christian Land in easternmost North Greenland, where the pre-Caledonian structures were regarded to be well preserved (Haller, 1970, p. 48). The Carolinidian fold belt was considered to extend from the northern part of East Greenland over most of North-East and North Greenland to northern Ellesmere Island in arctic Canada (Haller, 1970, fig. 18).

The Carolinidian orogeny as envisaged by Haller took place after the deposition of the 'Thule Group' ( $\approx$ Independence Fjord Group of Collinson, 1980, in the Proterozoic platform area of North Greenland) and before deposition of the later Proterozoic 'Hagen Fjord Group'. The sandstones of Haller's 'upper Thule Group' are referred to in this report as 'the Proterozoic sandstones'.

The existence of a pre-Caledonian, Carolinidian orogeny was based mainly on three lines of evidence: (1) the presence of distinct angular unconformities between the Proterozoic sandstones and the sediments of the Hagen Fjord Group (Haller, 1970, p. 48); (2) the differences in style and axial trends between the older Carolinidian and younger Caledonian structures (structural maps in Haller, 1970 and 1971); and (3) the presence of two generations of basic intrusions in the Proterozoic sandstones, one deformed during the Carolinidian orogeny and the second unaffected (Haller, 1970, p. 54).

As members of GGU's North Greenland expedition in 1980 we had the opportunity to study the 'type area' of the Carolinidian orogeny in some detail. The area investigated lies between Ingolf Fjord $\left(80^{\circ} 30^{\prime} \mathrm{N}\right)$ and Lambert Land $\left(79^{\circ} \mathrm{N}\right)$, but work was mainly concentrated on the Prinsesse Caroline-Mathilde Alper (fig. 2). Most of the terrain is relatively well exposed but extremely inaccessible. Many localities cannot even be visited by helicopter. The main aim of our field work was to study the Proterozoic sandstones and associated intrusives, and their relationships to the overlying rocks. We had six camps in, or very near, the Proterozoic sandstones, and further work was done by helicopter reconnaissance.

It will become clear from this report that our results, in many aspects, are not in agreement with Haller's findings, and it is only fair to emphasise that Haller's investigations were made under considerably less favourable conditions than ours. Most of Haller's observations in the northern part of the Caledonian fold belt were made during reconnaissance flights 


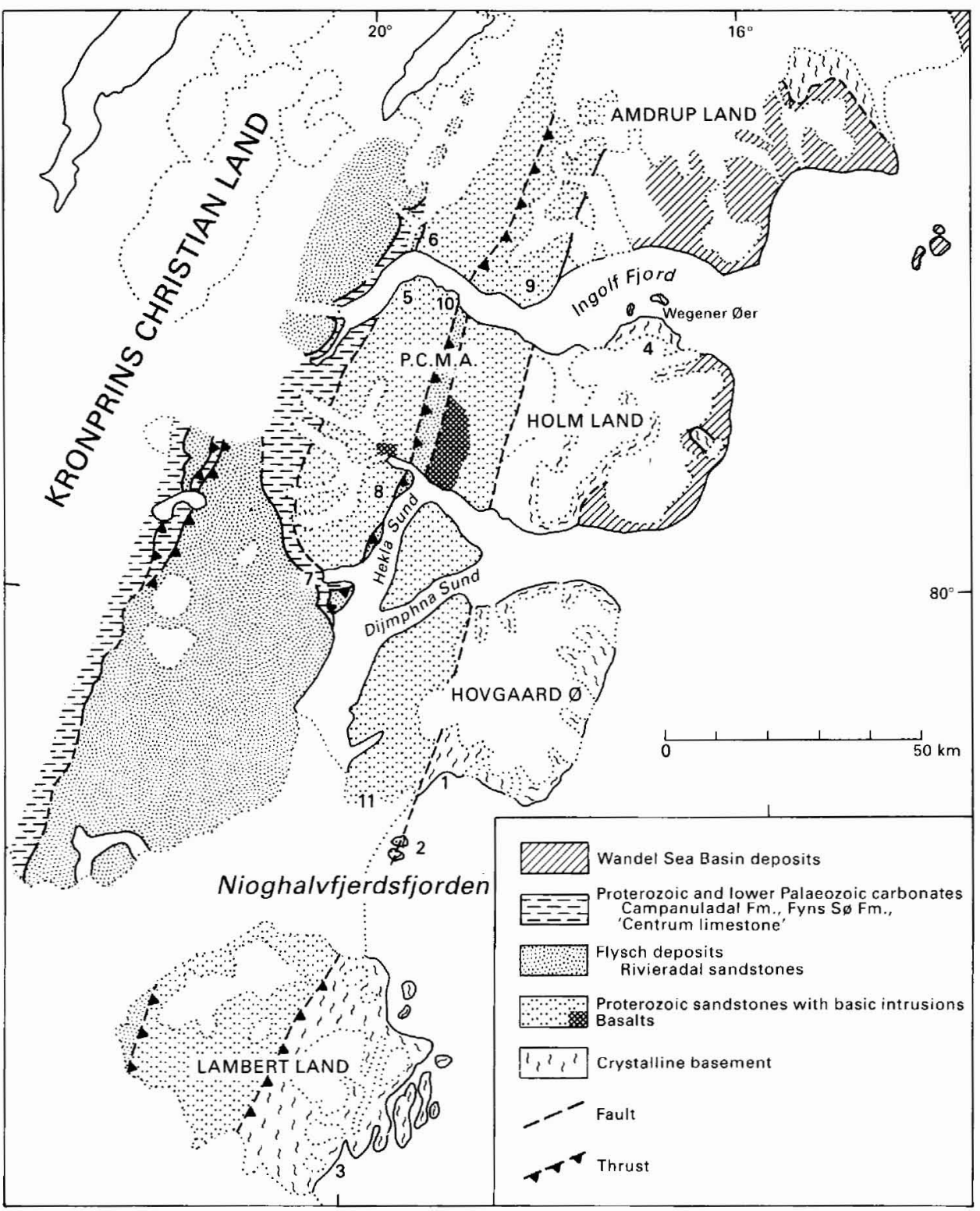

Fig. 2. Geological sketch map of the area between $79^{\circ}$ and $81^{\circ} \mathrm{N}$ in eastern North Greenland with localities mentioned in the text numbered 1 to 11. P. C. M. A. = Prinsesse Caroline-Mathilde Alper.

with fixed-wing aircraft, supplemented by only very few observations on the ground. The numerous photographs that accompany Haller's publications have been of great help in locating suitable outcrops for detailed investigation, and we have been able to study on the ground most of the localities that Haller could only see from the air. 


\section{Stratigraphy}

The Proterozoic sandstones are underlain by a crystalline basement that outcrops towards the east (fig. 2), and overlain to the west by sediments which Haller (1970) refers to the 'Hagen Fjord Group'. The contacts between these units and the Proterozoic sandstones are rarely exposed in the area studied because the sandstones are generally flanked by wide, moraine-filled valleys, glaciers or fjords. In one area the contact between the basement and the Proterozoic sandstones could be studied, and the contact between the Proterozoic sandstones and the younger sediments was exposed in three widely separated localities. A major unit of flysch-type deposits, referred to the Rivieradal sandstones (Fränkl, 1974; Hurst \& McKerrow, this report), also occurs in the area, but the stratigraphical relationships of this with the other units could not be established.

\section{Crystalline basement}

The crystalline basement occupies most of the eastern part of Holm Land, Hovgaard $\varnothing$ and Lambert Land. It consists of variable gneiss types, migmatised mica schists, amphibolitic rocks etc. On the south coast of Hovgaard $\varnothing$ (loc. 1, fig. 2) and on two islands near the front of the glacier in Nioghalvfjerdsfjorden (loc. 2, fig. 2), augen gneisses, presumably belonging to the basement, occur interfolded with the Proterozoic sandstones. No basal conglomerate was found at the contact.

Haller (1970, fig. 20) regarded part of the crystalline rocks as gneissified Thule Group. We have visited the locality shown on Haller's fig. 20 (loc. 3, fig. 2), but the gneisses exposed here are in no way different from the basement rocks seen elsewhere. In the area south of Wegener Øer (4, fig. 2), where we studied the basement in some detail, discordant basic dykes occur which cut the gneissic banding as well as folds in the gneisses. These dykes are themselves folded and metamorphosed to amphibolites, but they have not been migmatised.

We think that the crystalline rocks represent a true basement with respect to the overlying Proterozoic sandstones, and not the gneissified equivalents of sediments of the 'Lower Thule Group' Samples have been collected for isotopic age determination to check this conclusion.

\section{'Thule Group'}

The name 'Thule Group' is no longer used in the stratigraphy of East Greenland, here we will only use it when discussing Haller's work.

According to Haller (1970, p. 52) the Thule Group can be subdivided into a lower part, mainly consisting of some $3000 \mathrm{~m}$ of semipelitic rocks, and a higher part consisting of up to $3000 \mathrm{~m}$ of sandstones (our 'Proterozoic sandstones').

A. 'Lower Thule Group'. Although the rocks of the 'Lower Thule Group' should be widespread in Kronprins Christian Land (Haller, 1971, figs 18 and 24) we have not been able to confirm their presence. However, near the contact with the crystalline basement some mica schists are found which could possibly belong to the Thule Group. These mica schists are interleaved with the sandstones, but because the rocks are strongly folded here, it is equally possible that they belong to the crystalline basement complex and are intricately interfolded with the sandstones. Comparable mica schists do occur in the basement. 
Semipelitic rocks of the Lower Thule Group have also been reported from Hagen Fjord (Haller, 1971, fig. 28) and Vildtland (Haller, 1971, fig. 18) but although these areas have now been mapped in some detail no semipelitic rocks have been found underneath the sandstones.

The distribution of rocks of the 'Lower Thule Group' in Kronprins Christian Land as shown on Haller's (1971) fig. 18 suggests that, from the air, he may have misidentified the basaltic rocks and crudely layered dolerites that occur there as dark pelitic rocks, in the same way as he misinterpreted the Zig-Zag Dal Basalt Formation at Hagen Fjord as a sedimentary sequence (Jepsen et al. 1980).

B. The Proterozoic sandstones. The Proterozoic sandstones (Haller's 'Upper Thule Group') consist of quartzitic to feldspathic, pink or yellow to white sandstones, lithologically very similar to the sandstones of the Independence Fjord Group in the platform area of eastern North Greenland (Collinson, 1980). Like the sandstones of the Independence Fjord Group, the Proterozoic sandstones of Kronprins Christian Land contain numerous basic intrusions. The similarities in stratigraphic position (lowest sediments in the stratigraphy), the lithology and the presence of intrusive rocks make a correlation of the Proterozoic sandstones of Kronprins Christian Land with the Independence Fjord Group very likely. Major siltstone horizons as mapped locally in the platform area (Collinson, 1979) have, however, not been found in Kronprins Christian Land.

As in the platform area (Jepsen \& Kalsbeek, 1979) the basic intrusions vary from thick sills to discordant sheets and subvertical dykes. One type of intrusion commonly passes into another which in places gives the intrusions very irregular shapes. At one locality (5, fig. 2) a silicic intrusion ('flow breccia') of the same type as those found in the platform area (Jepsen \& Kalsbeek, 1979) was observed.

In the platform area the sandstones of the Independence Fjord Group are overlain by a sequence of basalts. Basaltic rocks also occur in Kronprins Christian Land, but here part of the basalts are sandwiched between sandstones with intrusions. It is not clear whether this is due to tectonic causes or to a difference in the stratigraphic development in the two areas.

\section{Overlying sediments}

At three localities the sedimentary contacts between the Proterozoic sandstones and the overlying sediments were studied.

At Hjørnegletscher (6, fig. 2) a locally irregular erosion surface in the Proterozoic sandstones with intrusions is overlain by $c .50 \mathrm{~m}$ of sandstones and shales, with a thin basal conglomerate. Although there is a clear unconformity, there is no distinct angular discordance between the Proterozoic sandstones and the overlying rocks, the bedding planes in both units being subparallel over a distance of several kilometres. The sandstone-shale unit is overlain by strongly sheared limestone that grades upwards into dolomitic rocks with stromatolitic structures, which are part of the late Proterozoic Fyns Sø Formation.

At Marmorvigen (7, fig. 2) the Proterozoic sandstones are overlain by a basal conglomerate (with local shale) and dolomite of the Fyns Sø Formation. Locally, stromatolitic structures in the dolomite have developed directly on boulders of the conglomerate. As at Hjørnegletscher, the conglomerates fill in an irregular erosion topography, but here also, 
there is no evidence of a distinct angular unconformity between the Proterozoic sandstones and the overlying Fyns Sø Formation.

On the west coast of Hekla Sund (8, fig. 2) a steep easterly dipping contact was seen between the Proterozoic sandstones and shales which probably are part of the Rivieradal unit (see Hurst \& McKerrow, this report). A basal conglomerate is present, followed by a few metres of strongly sheared limestones, which in turn are overlain (probably with tectonic contact) by shales of the flysch sequence.

At several localities near Marmorvigen the Rivieradal flysch sequence is in near contact with the Proterozoic sandstones, but always separated from them by a few metres of sheared limestone. The contacts are very steep to subvertical. No basal conglomerates were observed and the stratigraphical relationships between the flysch sequence and the Proterozoic sandstones are therefore not clear. The contacts are probably of a tectonic nature (see Hurst $\&$ McKerrow, this report). The rocks of the flysch sequence do not contain any intrusions and they are therefore probably younger than the Proterozoic sandstones.

\section{Structure}

\section{Main structures}

The outcrops of the Proterozoic sandstones can be divided into a western and an eastern part. The western part terminates near Marmorvigen in a south-plunging anticline with carbonate rocks and flysch-type sediments (Rivieradal sandstone) enveloping it. The occurrence of a basal conglomerate on top of the sandstones to the west, south and east confirms this structure. Shales (probably belonging to the Rivieradal unit) have been found at a number of localities in the wide valley separating the western and the eastern part of the Proterozoic sandstones, probably lying in a tightly compressed syncline. It is probable that this narrow syncline is also the site of a thrust plane, as a few metres of strongly tectonised limestone occur along the contact between the Proterozoic sandstones and the shales.

Hurst \& McKerrow (this report) have, in agreement with Fränkl (1954), interpreted the flysch sequence as forming a large nappe of late Proterozoic sediments, coming from the east. The evidence for this conclusion is that the flysch sequence, while stratigraphically overlain by the Campanuladal Formation and Fyns Sø Formation, lies structurally on top of these formations.

Fränkl (1954) thought that the Proterozoic flysch sequence (the Rivieradal sandstone) was deposited in what he termed the 'Hekla Sund Basin', situated where the median syncline that separates the Proterozoic sandstones into two parts now occurs. This model would require a lateral shortening across the area of perhaps more than one hundred kilometres, for which we have seen no evidence.

Hurst \& McKerrow (this report) consider that the flysch nappes root east of our mapping area. This model requires that the nappe movements were early in the structural history of the area. For example, the occurrence of the flysch sequence in the tight syncline between the two major outcrops of the Proterozoic sandstones indicates that the proposed nappe thrust movement is earlier than the formation of this syncline. 


\section{Folding and thrusting}

The Proterozoic sandstones and associated intrusions are strongly folded on a large scale (hundreds of metres to a few kilometres) with north and north-east trending, commonly subhorizontal axes. Most folds have east to south-east dipping axial planes with moderately dipping eastern limbs and steep to overturned western limbs. This style of folding is also found in the younger ('post-Carolinidian') sediments.

In the sandstones it is often difficult to see the folds. This is due to: (1) the monotony of the rocks - no clear marker beds can be followed for any distance; (2) the poorly developed bedding - in many places it is difficult to see the bedding planes, especially where the rocks are strongly deformed (and where the bedding is clearly visible, cross-bedding makes it difficult to obtain reliable measurements); and (3) the irregular shapes of the intrusions where the intrusions are proper sills they are very helpful in defining fold structures, but where they are discordant or of irregular shape they may give a very misleading impression of the folds in the sandstones themselves.

It is probable that thrusts occur in the sandstone units, but owing to the lack of a detailed stratigraphy it is rarely possible to prove that a thrust is present even where the sandstones are strongly sheared. Several of the thrusts indicated on Haller's (1970) plate XI (north shore of Ingolf Fjord, just east of loc. 6, fig. 2) could not be confirmed in the field.

In the western part, the Proterozoic sandstones, though folded, commonly do not show signs of penetrative deformation; cross-bedding and ripple marks are here well preserved. Towards the east, steep belts of strongly sheared, schistose (sometimes calcareous) sandstone become common, alternating with well preserved sandstone. In these zones the dolerite dykes are often boudinaged and/or strongly sheared. In the eastern part of the sandstone outcrop large scale folds are less commonly seen, and in general the bedding and cleavage dip regularly, steeply eastwards. Here also, intensely sheared rocks alternate with relatively well preserved sandstones and dolerites. The latter are mostly concordant with the general structure in the sandstones, and often boudinaged. It is possible that some of the shear belts represent thrust planes, but at one place in Ingolf Fjord $(9$, fig. 2$)$ a large $(500 \mathrm{~m}$ high) isoclinal fold occurs in a zone of strongly sheared rocks and there is no evidence of large scale thrusting.

In the younger ('post-Carolinidian') rocks the structures are of the same style as in the Proterozoic sandstones. Shales almost invariably show an east dipping slaty cleavage, and in folds where the bedding can also be seen it is evident that this is an axial plane cleavage. In carbonate rocks the bedding is rarely visible and a common east dipping cleavage or jointing is considered to be of tectonic origin. The easterly dipping axial planar cleavage is steep to subvertical in the eastern part of the Proterozoic sandstones, but becomes gradually flatter towards the west through the carbonate rocks and into the Rivieradal sandstones.

According to Haller (1970, p. 57; 1971, p. 63) Caledonian deformation in Kronprins Christian Land was mainly restricted to thrusting, most of the folds being of Carolinidian age and having NE-SW to ENE-WSW axial trends. Large 'Carolinidian' folds in the inaccessible southern walls of Ingolf Fjord (10, fig. 2) are shown on Haller's fig. 19 (1970) to have a c. $30^{\circ}$ ENE plunging axis. However, measurements in the outcrops beneath the steep wall in which these folds are seen gave strikes of $10-20^{\circ}$ east of north on subvertical beds, and, since for geometrical reasons vertical beds in a fold structure must be parallel with the trend of the fold axis, the axis cannot be ENE. 
To check whether there is a difference in axial trends between the folds in the Proterozoic sandstones and the later sediments (which can only have been affected by the Caledonian orogeny), an attempt was made to measure systematically the orientation of minor fold axes in the two sequences. However, minor folds, especially in the Proterozoic sandstones, are rarely so well exposed that the orientation of the axis can be readily measured. Since the trend of the fold axes is of special interest here, the strike of subvertical beds ( $\geq 80^{\circ} \mathrm{dip}$ ) was also measured since these are parallel with the trend of the local fold axis. Diagrams of such trends/strikes are shown in fig. 3. It is clear that there is no large difference in axial trends. In both the older and the younger sediments the trends vary from $c$. N-S to $c$. NE-SW.
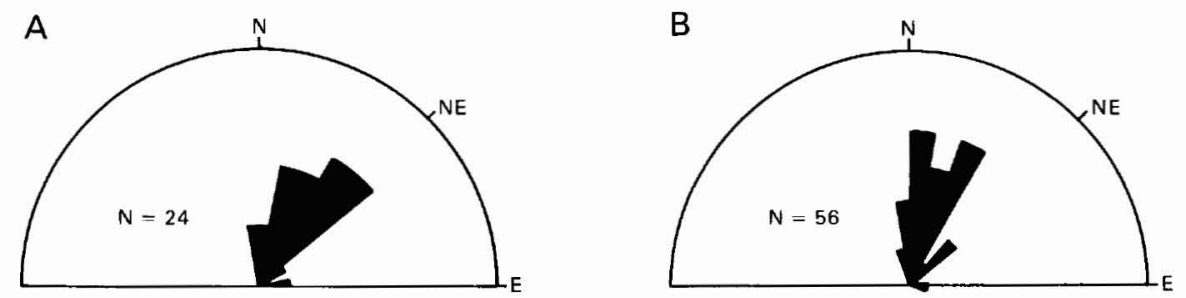

Fig. 3. Trends of minor fold axes and strikes of subvertical beds. A: Proterozoic sandstones. B: Overlying ('post-Carolinidian') sediments.

\section{Deformation of the basic intrusions}

According to Haller (e.g. 1970, p. 54) there is evidence for two periods of basic intrusion, the earlier intrusions being deformed during the Carolinidian orogeny and the later affected only by superficial Caledonian deformation.

In the platform area (Jepsen \& Kalsbeek, 1979) it is common to find intersecting intrusions, but there is no evidence that there are two distinct major phases of Proterozoic igneous activity. In the Proterozoic sandstones of Kronprins Christian Land intersecting intrusions are also common, but again we have not seen evidence of two major phases of intrusion. It is true that some intrusions are folded and others not, but this may well be explained by the orientation of the intrusions with respect to the deformation geometry. In large parts of the Proterozoic sandstone terrain the axial planes of the folds are steep to subvertical, and subvertical dykes may therefore not show the folding. We have seen several examples of intrusions that locally are strongly sheared and elsewhere well preserved, depending on the location of the intrusive rock with respect to the folds in the sandstones.

We have visited several of the localities shown in Haller's (1970) photographs. The 'older intrusion' at loc. 5, fig. 2 (Haller's Plate XII) is in reality a unit of dark shales, belonging to the younger Proterozoic sequence seen at Hjørnegletscher, which here are infolded in the Proterozoic sandstones. The 'younger dyke' is strongly deformed and does not penetrate into the dark shales. The 'post-Carolinidian generation of Thulean basalts' at loc. 11 (fig. 2), shown in Haller's fig. 17, consists of wide vertical dykes, more or less parallel with the axial planes of the folds in that part of the area. The dyke rock, as well as the surrounding sandstones, have a widely spaced fracture cleavage parallel with these axial planes. In the same general area more strongly deformed rocks occur where both the sandstones and vertical dykes have developed a strong cleavage and the dykes are locally boudinaged and often completely altered to greenschists. 


\section{Conclusions}

As noted in the introduction, Haller's arguments for the existence of a Proterozoic Carolinidian orogeny in eastern North Greenland were: (1) the presence of angular discordances between the Proterozoic sandstones and younger Proterozoic sediments; (2) the difference in tectonic style and structural trend between the older and younger Proterozoic rocks; and (3) the occurrence of two suits of basic intrusions, the older one predating the Carolinidian orogeny.

As described in the preceding sections, none of these points could be verified during our field work. It is true that the Proterozoic sandstones underwent uplift and erosion before the younger Proterozoic sediments were deposited, but no angular discordance has been observed. Major periods of erosion have also been recorded in the platform area at several stratigraphical levels, for example within the Independence Fjord Group (Collinson, 1979), at the base of the late Proterozoic Campanuladal Formation (Jepsen et al. 1979), at the base of the Early Cambrian Portfjeld Formation (Jepsen, 1971), and at the base of the Ordovician Wandel Valley Formation (Christie \& Peel, 1977). Such unconformities do not imply the existence of a preceding orogeny.

The structures in the 'pre-Carolinidian' and 'post-Carolinidian' sediments are comparable both in structural style and in axial trends, and can therefore all be ascribed to the Caledonian orogeny.

We have seen no evidence for the existence of two distinct major phases of igneous activity, and study of localities where according to Haller's illustrations such evidence should be most clear gave negative results.

Thus, since we have seen no evidence to support its existence, we see no reason to assume that a Carolinidian orogeny took place in Kronprins Christian Land.

\section{References}

Christie, R. L. \& Peel, J. S. 1977: Cambrian-Silurian stratigraphy of Børglum Elv, Peary Land, eastern North Greenland. Rapp. Grønlands geol. Unders. 82, 48 pp.

Collinson, J. D. 1979: The Proterozoic sandstones between Heilprin Land and Mylius Erichsen Land, eastern North Greenland. Rapp. Grønlands geol. Unders. 88, 5-11.

Collinson, J. D. 1980: Stratigraphy of the Independence Fjord Group (Proterozoic) of eastern North Greenland. Rapp. Grønlands geol. Unders. 99, 7-23.

Fränkl, E. 1954: Vorläufige Mitteilung über die Geologie von Kronprins Christians Land (NE-Grönland). Meddr Grønland 116 (2), 85 pp.

Haller, J. 1961: The Carolinides: an orogenic belt of late Precambrian age in Northeast Greenland. In Raasch, G. O. (edit.) Geology of the Arctic 1, 155-159. Toronto U.P.

Haller, J. 1970: Tectonic map of East Greenland (1:500 000). An account of tectonism, plutonism, and volcanism in East Greenland. Meddr Grønland 171 (5), $286 \mathrm{pp}$.

Haller, J. 1971: Geology of the East Greenland Caledonides. 413 pp. New York: Interscience Publishers.

Hurst, J. M. \& McKerrow, W. S. 1981: The Caledonian nappes of Kronprins Christian Land, eastern North Greenland. Bull. Grønlands geol. Unders. 96 (also Meddr Grønland 192,2) 42 pp.

Jepsen, H. F. \& Kalsbeek, F. 1979: Igneous rocks in the Proterozoic platform of eastern North Greenland. Rapp. Grønlands geol. Unders. 88, 11-14.

Jepsen, H. F., Kalsbeek, F. \& Suthern, R. J. 1980: The Zig-Zag Dal Basalt Formation, North Greenland. Rapp. Grønlands geol. Unders. 99, 25-32. 